Mario Vrbančić, University of Zadar, Croatia - Senka Božić-Vrbančić, University of Zadar, Croatia

\title{
FILMSKI DODIR: interkulturalno haptičko i dekolonizacija misli
}

\section{Abstract: Touch of the Film: Intercultural Haptic Visuality and Decolonization of Thought}

Haptic visuality is for Laura Marks the possibility of vision to be tactile, "as though one were touching a film with one's eyes." An intercultural visual work, for Marks, more than any other work does this sensory exploration. This article does both: it builds on Marks's work on haptic visuality and distinguishes its reading of the possibilities of an intercultural work to translate to "an audiovisual medium the knowledge of the body." Inspired by a relatively recent anthropological school of thought, developed particularly around the works of Eduardo Viveiros de Castro, the article offers new readings of haptic visuality and invites us to think of the political dimension of film and the role of haptic translation as a possibility of decolonization of thought.

Keywords: haptic cinema, intercultural haptic, horror haptic, oriental haptic, Deleuze \& Guattari, Benjamin, Viveiros de Castro

Kako se sve može iskusiti zvuk, boja, gesta, u kolikoj mjeri i na koji način ta iskustva u nama bude osjećaje radosti, boli ili mučnine? Je li film medij koji u nama može probuditi taktilnu percepciju, ili je sve sinestezija, zapravo „prevođenje” iz jedne sfere percepcije u drugu? Pa i ovo pisanje je, zapravo, čin prevođenja, jer pišemo o filmu, zvuku, pa i o našem doživljaju filma - sve je dakle ovdje prevođenje u riječi. Prevođenje se odnosi i na čitanje teksta, onoga što je napisano u doživljaj pročitanoga. Često se riječ prevođenje koristi samo u kontekstu procesa prevođenja iz jednog jezika u drugi, ali prevođenje može ići beskonačno: kao prevođenje jedne kulture u drugu ili 
prevođenje jednog osjetila u drugo osjetilo. No prevođenje, međuodnos između originala i njegove prevedene destinacije, pa čak kad se radi i o onom što nam na prvi pogled izgleda kao najjednostavnija prevoditeljska tranzicija, nije tako jednostavno (Benjamin 253-63). Kao što Walter Benjamin naglašava, prevođenje je uvijek puno prijepora. Ovaj rad pokušava dočarati te momente prijepora u prevođenju jednog osjetila (vizualnoga) u drugo (taktilno). Postavlja se pitanje može li nas filmski medij „dotaknuti”, može li se vizualno prevesti u taktilno i obrnuto.

Pitanje taktilnosti filma u filmskoj se teoriji javlja kao haptička filmska kritika. U ovom radu posebnu pozornost posvećujemo radu Laure Marks, koja izvore taktilnosti u filmu pronalazi u eksperimentalnoj i interkulturnoj kinematografiji koja je nastala između 1985. i 1995. godine, kada je pitanje multikulturalizma obilježilo Zapad (The Skin). Za Marks „kinematografija nije fundamentalno verbalna“ (The Skin vi), ona simultano ima intelektualne, emocionalne i visceralne efekte. Ono što nju primarno interesira način je na koji se filmom formira značenje, i to ne samo na razini znakova već i tjelesnih senzacija kao što su dodir, miris i okus (The Skin vii). Interkulturalni se film za Marks odlikuje „eksperimentalnim stilovima koji pokušavaju prikazati iskustvo života između dviju ili više kultura, između različitih formi znanja“ (The Skin 1), i često ima mimetičke efekte. Jedan od njezinih uzora i glavna teorijska inspiracija su Deleuze i Guattari i njihov koncept haptičke slike. Oni otkrivaju haptičko u multidisciplinarnom iskapanju arheologije znanja povijesti umjetnosti s početka dvadesetog stoljeća, ponajviše u vizualnom arhivu egipatske civilizacije, koji se proteže, u raznim varijacijama, sve do modernog i, danas bismo rekli, postmodernoga vizualnog izričaja. Za njih je važno pitanje koliko su vladajući, državna moć i razni oblici društvene kontrole, skloni optičkom prikazivanju zbilje kao sustavu klasificiranja znanja koje služi pokoravanju te može li haptička slika poslužiti izmicanju sveopćoj kontroli? No upravo je ta dimenzija „izmicanja” po našem tumačenju problematična u čitanju haptičkoga kod Marks. Stoga u ovom radu kroz kritički odnos prema čitanju haptičke slike otvaramo prostor i za drugačija čitanja haptičkoga. Postavljamo pitanje da li osim eksperimentalnog i interkulturalnog filma koji izrazito rabi haptičku sliku, postoje i neki drugi vidovi filmske proizvodnje koje se bave haptičkim? Proširujući Marks, dolazimo do primjera haptičkoga korištenog u druge svrhe, kao na primjer u erupciji strave (horor haptičko), pa u trenucima sučeljavanja s radikalnim drugim (orijentalno haptičko) i krajnja zbunjujuća instanca kada filmski total postaje haptički (kozmičko haptičko). Na kraju problematiziramo pitanje 
„prevođenja” te inspirirani radom Waltera Benjamina, kao i brazilskog antropologa Eduarda Viveiros de Castra, zaključujemo da prevođenje može otvoriti nove emancipatorske potencijale, jer ono što se prevodi nije samo jedna percepcija u drugu (na primjer vizualno u osjetilno). Ako je, kao što to Benjamin tvrdi, prevodivost osnovno načelo svih prevođenja, onda se ona odnosi na sâm život, na prevođenje života koji i kad uključuje radikalnu Drugost još uvijek na neki način komunicira s nama, „dozvoljava stranim konceptima deformiranje i subverziju prevoditeljskih umijeća i to na način koji omogućava ekspresiju originala u novoj formi" (Viveiros de Castro 5).

\section{Taktilnost filma}

U početku dvadesetog stoljeća, filmska praksa kao i filmska teorija, osupnuta kinetičkom snagom filma i eksplozivnim mimetičkim mogućnostima novog medija, pridaje veliku pozornost šoku te slavi filmsku potenciju približavanja pojavnosti, stvari, događaja. Isto tako slavi i tjelesni odgovor na filmsku percepciju, pokušavajući razgraničiti film od ostalih umjetnosti, kazališta, književnosti, slikarstva. U tom traženju razlikovnosti film se imenuje kao „skulptura u pokretu”, „glazba svjetla”, „pokretne slike” ili kao „slikarstvo obdareno pokretom”. Težilo se pronalasku „čisto filmskoga”, onoga što čini film različitim od drugih umjetnosti. Fotogeničnost je trebao biti taj neizrecivi element, esencija filma koja ga čini različitim naspram ostalih umjetnosti. Paradoksalno, jedan od najznačajnijih pomaka k „čistom filmu” (pure film), blizak je onome što se kasnije u filmskoj teoriji naziva haptički film. Filmsko iskustvo je, kao što to navodi Robert Stam, u samim svojim počecima već uključivalo tjelesnost. Po Stamu, zahvaljujući filmu: „... mi doživljavamo brda, stabla, lica u prostoru kao posve novu senzaciju. Zahvaljujući pokretu i pojavnosti, samo tijelo doživljava dubinu prostora... Filmska kamera, više nego automobil ili zrakoplov, omogućuje personalne doživljaje koji vibriraju tjelesnim svijetom." (35). Fotogeničnost koja uključuje i tjelesnost filma možda se najbolje vidi u filmovima Jean Epsteina koji mobilizira senzibilnost i osjetila filmske publike u izravnom kontaktu s ljudskim tijelom, licem, nogama, rukama! ${ }^{[1]}$ Međutim, u filmskoj teoriji taj se taktilni pristup filmu gubi s pojavom strukturalističke paradigme kada prevladava čitanje filma kao teksta, strukture, kao filmskog znaka, a ono senzualno, mesnato biva potisnuto ili podjarmljeno raznim sustavima. Posljednjih par desetljeća u filmskoj teoriji i studijima filma sve više jačaju pristupi koji se bave filmom ne samo kao strukturom, filmskom gramatikom, filmskim jezikom nego teoretiziraju 
i bave se osjetilima, afektom, emocijama, što se podudara s brojnim antropološkim, sociološkim i kulturološkim istraživanjima društva. Interdisciplinarni interes za razne manifestacije kao i konceptualizacije osjetila, emocija i afekata, iako nemoguć za sažeti u jednu liniju mišljenja, često nosi naziv afekt teorija. Afekt teorija zapravo je sinonim za analizu susreta između tijela i stvari, tijela i svijeta, za ono što bismo mogli nazvati „bivanjem u svijetu” (Gregg and Seigworth 1-25). Obraćanje pozornosti na materijalnost na razini osjetila, emocija i afekata otkriva bogat iskustveni svijet individua jer afekti su uvijek vezani za stvari, ljude, ideje, odnose, ambicije, institucije itd. Za teoretičare koji pripadaju afektivnom obratu u društveno-humanističkim znanostima osjetila, emocije i afekti su ne samo korisni već i ključni za razumjeti ljudsko iskustvo i razne svjetonazorske povijesne putanje koje određuju to iskustvo[?]

Filmu i vizualnoj umjetnosti kao formi koja omogućava transmisiju afekata na osjetila gledateljstva pristupa teoretičarka Laura Marks. Može se reći da je ona jedna od začetnica, a i jedna od glavnih pobornica tog pristupa. Ona poziva na promatranje filma i vizualne umjetnosti na drugi način, osobno, impresionistički, tjelesno. Njen se pristup primarno fokusira na sâm proces transmisije, tj. na fenomenološko iskustvo gledanja filma. Osjetima koji nisu imanentno filmski (virtualno tjelesno, tjelesno virtualno, sinestezija), Marks pristupa s naglaskom na pogled koji „dotiče” gledano, to jest kad „oko služi kao ruka”, kad oko omogućava tjelesnu senzaciju. Tako, na primjer, u svojoj knjizi Touch, Sensuous Theory and Multisensory Media ona opisuje svoj doživljaj gledanja videa Sadie Benning, It wasn't love (1992.):

Ne događa se puno u priči. Najsnažniji je trenutak kad Benning, polako, siše svoj prst; par centimetara udaljena od kamere slabe rezolucije, izvan fokusa. Ipak gledanje te snimke vodi me u posebno stanje erotske drhtavosti; do čežnje za intimnom blizinom s Drugim; bolna ali uzbudljiva svjesnost njezine prisutnosti, koja je toliko bliska ali i nedostižna; toliko sam prožeta Drugim da postepenom gubim granice, osjećaj proporcije kada velike stvari nestaju iz horizonta moje pozornosti a male postaju poprište svemira osjećaja. (1)

Pogled koji „dotiče” gledano Marks naziva haptičkim, inspirirana Alois Rieglovom (1858-1905) distinkcijom između haptičke i optičke slike. Riegl, proučavajući povijest umjetnosti razlikuje vizure koje su taktilne (ornamentistika, Egipatska umjetnost) i optičke (apstraktna prostornost i figurativnost koja se može naći u kasnoromanskoj umjetnosti) ${ }^{[3]}$ Rieglova distinkcija inspirirala je i 
Waltera Benjamina koji je, upravo suprotno Rieglu, modernu percepciju promatrao kao taktilnu, kao izazov osjetilima. Nadalje inspirirala je i Deleuzea i Guattarija koji uvode distinkciju između "glatkog” i „naboranog” mjesta. Glatko mjesto je mjesto događaja i intenziteta, ono je haptičko, to je mjesto gdje nema perspektive u vidljivom i stalno moramo navigirati, kao nomadi, dok je naborano mjesto optičko, ono omogućava pogled u daljinu. Haptičko i optičko međutim nikad nisu u potpunosti razdvojeni, oni uranjaju jedno u drugo.

U suvremenoj filmskoj teoriji pojam haptički prvi rabi Noel Burch kao način na koji film stvara prostornu iluziju, fokusirajući se primarno na optičku formu (Bruno). Upravo suprotno tom pristupu, Marks, inspirirana Benjaminom, kao i Deleuzeom i Guattarijem naglašava mogućnost taktilnosti filma. Do oka kao „organa dodira”, do haptičke dimenzije filma, Marks dolazi posredno, baveći se interkulturalnim, dijasporičnim filmom. Svoju teoriju, koja je inspirirala čitav niz afektivnih i osjetilnih pristupa filmu i vizualnoj kulturi ${ }^{[4]}$ Marks predstavlja u dvije knjige: The Skin of the Film, Intercultural Cinema, Embodiment, and the Senses i Touch, Sensuous Theory and Multisensory Media. Kako bi počeli promišljanje taktilnosti filma prvo ćemo ukratko predstaviti njen rad, a potom pokazati da haptički film itekako nadmašuje transmisiju osjetila iz vizualnoga u tjelesno na način na koji o tome govori Marks. S obzirom da smo ograničeni dužinom ovog rada, pozornost ćemo usmjeriti prema drugim mogućnostima čitanja haptičkoga koje proizlaze iz Deleuzeove i Guattarijeve definicije „haptičkoga” kao i poimanja „prevođenja”, a čije aspekte Marks ne uzima u obzir $[5]$

\section{Dodir kože, dodir filma, interkulturalno i manjinsko haptičko}

Osnovno pitanje u knjizi The Skin of the Film, Intercultural Cinema, Embodiment, and the Senses odnosi se na interkulturalna iskustva te u kojoj mjeri ona postaju presudna za filmski stil, i koliko sam taj stil (tradicionalno rečeno forma) zapravo postaje „poruka” (sadržaj) Po Marks postoji nešto u interkulturalnom iskustvu što ga čini posebnim - doživljaj egzistencije u dijaspori, iskustvo izmještenih, prognanih, u egzilu. Stoga se Marks bavi onima koji žive izvan mjesta u velikim svjetskim metropolama te nam pokušava približiti filmsku ekspresiju video umjetnika, filmskih djelatnika, performera, koji su se našli u velikim zapadnoeuropskim metropolama: imigranti iz Azije, Karipskih otoka, Bliskog istoka, Afrike, Latinske Amerike. Njezina temeljna tvrdnja je da ti umjetnici 
kao pripadnici manjina u šarolikim kozmopolitskim sredinama koje su još uvijek primarno određene „bjelinom” pokušavaju svoju izmještenost prikazati na novi, drugačiji način. Interkulturalni film, kakvim ga ona vidi, obilježava eksperimentiranje sa stilovima u potrazi da se izrazi to dijasporično manjinsko iskustvo koje se ne da uklopiti u monolitno kulturno zdanje Zapada, nego hibridno struji iz jedne u drugu kulturu. To iskustvo svakako, više ili manje, proizlazi iz nasilnog izmještanja iz određenih prostorno-vremenskih koordinata, ono je prisiljeno na čitav niz „prevođenja” grčevito tražeći, često s idealističkim nabojem, original - prvotni tekst, što se u dijasporičnom kontekstu veže uz domovinu. Benjaminovo propitivanje originala u kontekstu prevođenja, u sferi interkulturalnog filma kao „prevođenja” jedne kulture u drugu, postaje ključno za Marks. To prevođenje „domovine” kao originala koji nužno mijenja prevoditeljsku destinaciju odnosi se, po Marks, osim verbalnoga i vizualnoga na prevođenje niza raznih osjetila, to jest ono postaje haptička filmska slika.

Marks naglašava da domovina u interkulturalnim filmovima nije nužno samo mjesto odakle emigranti dolaze, domovina je kulturna memorija koja se pokušava njegovati u mjestima gdje se oni nalaze. Interkulturna kinematografija omogućava rekreiranje nekih povijesnih događanja, i iako uglavnom predstavlja povijest kroz osobne priče, ona nudi jedan drugi pogled na širi kontekst koji je uglavnom bio obilježen kolonijalnom dominacijom Zapada i drugim velikim povijesnim događanjima. Interkulturalni film kao forma ima tu mogućnost predstaviti ne samo ono što je vidljivo ili izrečeno već i ono što se može osjetiti. Marks kao primjer navodi niskobudžetni film Reae Tajiri History and Memory: For Akiko and Takashige (1991) u kojem se autorica filma bavi sjećanjima svoje obitelji na povijesni period tijekom Drugoga svjetskog rata kad su Japanci u Americi bili zatvoreni u logorima - stotinu i deset tisuća japanskih obitelji pod sumnjom da surađuju s neprijateljem ili da su jednostavno prijetnja Americi. U usporedbi sa službenom historiografijom, dokumentima i vizualnim arhivom, taj traumatski događaj kojeg se obitelj nerado sjeća, potpuno je neznatan mikrokozmos. Taj nesrazmjer ujedno obilježava stil filma: Tajiri sučeljava tu bujicu slika, dokumenata, audio slika i snimljenih intervjua s praznim ili crnim ekranom na kojem možemo čitati pomičan tekst i čuti njen glas (voice over): „Ne znam odakle je došlo, ali imam samo jedan fragment, jednu sliku koja mi se često javlja. Moja majka stoji na pročelju i puni kantu hladnom 
vodom. Tople sunčeve zrake, i uskovitlana prašina, jer se neprestano čiste podovi." (Marks, The Skin 32).

Ovdje crni ekran, tišina, svjedoči o nepremostivim preprekama u naporima da se izrazi memorija u interkulturalnom filmu. Memorija dijaspore u svjetskim metropolama često dolazi do zastoja, prepreke koje ukazuju na svojevrsnu neizrecivost, do tišine, do potrage da se nanovo istražuje arheologija filmskih i digitalnih zapisa. Nesrazmjer između službenih vizualnih arhiva i osobne memorije samo pojačava razne varijacije osjećaja iskorijenjenosti, gubitka domovine u svim nijansama, tonovima i intenzitetima te se posebno ističe u memoriji važnih, traumatskih događaja. Nadalje, u interkulturalnom filmu, navodi Marks, haptička vizualnost često se veže uz pojedine predmete, objekte, koji su fosilizirani ostaci davnih uspomena, malih katastrofa. Ti su predmeti, kao i njihovi vlasnici, u egzilu, izvan svog konteksta, objekti memorije, memorija-objekti. U Tajirinoj History and Memory tako funkcionira komad ter papira koji je Tajiri našla. Taj papirnati objekt koji je otpao s krova barake gdje je bila zatvorena njezina majka, taj istrošeni, sivkasti objekt izložen na crnoj podlozi izgleda kao fotografirani dijamant.

Nadalje Marks navodi kako globalna tržišna ekonomija ubrzava opticaj predmeta koji postaju globalne robe. Mislimo da je u tom opisu vrtoglavog strujanja predmeta-roba, Marks bliska postmarksistima, koji se, kao na primjer Frederic Jameson, bave tom nevidljivom dimenzijom kapitala - brisanjem, poništavanjem, potiskivanjem uvjeta proizvodnje pojedinih globalnih roba (na primjer nehumanih uvjeta rada i malih plaća u zemljama Trećeg svijeta) ${ }^{[6]}$ Brisanjem onih koji su sudjelovali u njihovoj proizvodnji, nestaju ruke koje su doticale te objekte, oblikovale predmete, pakirale u ambalažu - dakle čitav taktilni spektar ili određena haptička dimenzija.

Upravo u tom čvorištu, gdje se gubi haptička dimenzija robe, u njihovoj fosilizaciji prastare domovine, ti predmeti i sami postaju „emigranti” ili, kako ih Marks zove, „transnacionalni objekti”. Prefiks „trans” pojačava tranzitnost raznih predmeta u kojoj se gubi osjećaj domovine i bilokakvoga supstancijalnog konteksta. To su trans-fetiši i trans-fosili čija uznemirujuća svjetlost pobuđuje gotovo istovremeno fetišističku zaslijepljenost i umirujuću fosilizaciju. Oni podsjećaju na Benjaminovu „auru”, odsjaj originalnosti kojoj se nikako ne možemo do kraja približiti, dotaknuti u svojoj jedinstvenoj singularnosti (Marks, The Skin). 
Osim ove globalne dimenzije dodira, interkuturalni film teži prizvati osobne memorije azilanata koje počivaju na dodiru. U filmu Shaune Beharry Seeing Is Believing (1991) Beharry teži pokazati dodir kože vezan uz uspomene preminule osobe (Marks, The Skin 127). Oplakujući smrt svoje majke autorica je želi još jednom prizvati u sjećanje; oblači njezin sari, materijal koji je dodirivao kožu majke sada dodiruje Shauninu kožu. Poniranje kamere u nabor sarija želi pokazati taktilne memorije, pratiti put haptičke slike sve dok se nabori sarija ne rastvore u nedefiniranu sivkastu masu (Marks, The Skin 128).

Ukratko, interkulturalni film u potrazi za identitetom izmještenih, u težnji da prikaže iskustvo ljudi koji žive u dijaspori, tvrdi Marks, poseže za posebnim stilskim sredstvima kako bi prikazao taktilnost memorije. Kada se susretnu dvije ili više kultura, kada ljudi žive u tom hibridnom stanju rađa se nova vrsta senzualnosti, to jest traže se nove prezentacije tijela, življenja u tijelu. One prve senzualne memorije domovine kao da su izbrisane ili intenzivno na putu nestajanja, taj bolni intenzitet nestajanja film je prisiljen prikazati na novi način (često postupcima koji su već korišteni u eksperimentalnom filmu). Ti postupci ne teže toliko umjetničkom obogaćivanju filmskog izričaja koliko iskazivanju iskustva koje se ne može ukalupiti u dominanti povijesni ili ideološki narativ. Stoga interkulturalni film teži pobuditi senzualnost, upustiti se u istraživanje osjetila koja nadilaze, ili mu ne pripadaju, audiovizualno područje - okus, dodir, miris. Marks zastupa tezu da interkulturalni film ponajviše počiva na raznim filmskim postupcima koji pobuđuju taktilnu memoriju, memoriju koja se nalazi u tijelu dijaspore, u dijasporičnim tijelima i transnacionalnim objektima, a sve to dovodi, ili se odvija posredstvom haptičke vizualnosti. Haptička vizualnost obično se javlja zbog nedostatka, nejasne konfiguracije koja priziva druga osjetila da pomognu pri orijentaciji. Haptička vizualnost je dakle drugačije gledanje i spoznaja o vidljivom koja je puno neposrednija, zahvaća cijelo tijelo; oči se ponašaju kao organ dodira, kao ruke koje klize po površini.

U knjizi Touch, Sensuous Theory and Multisensory Media Marks proširuje polje interkulturalnog filma obogaćujući ga novim manjinskim i medijskim iskustvima. Ta „rubna područja” ujedno su i važna za nove i drugačije eksperimente s haptičkom slikom. Na primjer heteroseksualna žena koja gleda gay pornografski film, gledanje životinja i izloženost pogledu životinje, gledatelj sučeljen s filmom u raspadu (koji uvijek mora biti negdje zabilježen, bilo da je to filmska vrpca ili videozapis), mogućnost da haptička filmska slika probudi osjet mirisa, pa i digitalni online prostor kao nešto 
imanentno materijalno nasuprot općeprihvaćenom shvaćanju digitalnoga kao transcendentalnoga i virtualnoga. Kao i za interkulturalni film, eksperimenti nisu važni sami po sebi, nego upravo onoliko koliko nam uspijevaju približiti ta granična iskustva, osjećaj iskorijenjenosti i nepripadanja.

Taktilnost ne mora biti nužno samo u prikazanome; ona se može nazrijeti i u samoj tehnologiji na kojoj se zasniva audiovizualna proizvodnja. Kad dodirnemo okom filmsku kožu koja se raspada, gubi jasne obrise, svjedočimo o samoj materijalnosti forme, njezinom nestajanju, koje budi asocijacije o umiranju filma, videa i filmske publike. Tako na primjer, Peter Delpetu u svome kolažnom filmu Lyrical Nitrate (1991), devastira videovrpcu koristeći nitrat. Stare filmske reportaže o rudarima, brodolomcima, biblijske motive o Adamu i Evi, sve to nagriza emulzija, sve postaje još starije, nestvarnije, na rubu nestajanja. Isto tako, filmovi Atoma Egoyana poigravaju se sa starim videozapisima kao analognom memorijom, raspad slike podsjeća na gubitak memorije, meditacija o aurama slika koje blijede, nestaju, tonu u zaborav. Ovdje se sâm nosač zvuka ili slike izlaže opasnostima - dekonstrukciji filmske ili videovrpce - kako bi se ukazalo na prolaznost. Prolaznost filma tema je i kratkog videa Sniff (1996), u kojem autor Ming-Yuen S. Ma uspoređuje film s mirisima koji nestaju (Marks, Touch 94). Čovjek se ustaje iz kreveta i njuši uokolo nastojeći namirisati miris svoje ljubavnice koja je nepovratno napustila sobu. Dok se on lagano kreće po sobi i njuši, njegov nos kao falična tražilica uzaludno lovi posljednje tragove mirisa voljene osobe, a istodobno s nestajanjem njezinih mirisa i slika polako blijedi, kao da se raspada - sve je na rubu da padne u zaborav.

Mirisi dovode do znanja koja su često potisnuta u ljudskim životima, kao u filmovima braće Quay, Timothy and Stephen Quay, posebno u njihovu prvome dugometražnom igranom filmu Institute Benjamenta or, This Dream People Call Human Life (1995) (Marks, Touch 128-33), gdje se ljudski život raslojava, dolazi do prevlasti mikroskopskog, neorganskog života. Inspiriran romanom Roberta Walsera Jakob von Gunten (1909) o institutu, to jest školi u kojoj polaznici uče postati savršene sluge, sedam polaznika (neki u ljubavnim zapletima), ponavljanjem i vježbanjem uslužnih djelatnosti postepeno se ukalupljuju, postaju ljudske mašine te se na kraju čitav taj pedagoški stroj raspada, a škola ukida. Osim ponavljanja radnji i vježbanja poslušnosti, identitet sluga postaje dio kuće koja djeluje kao mašina, a mrtve prirode i stvari kao da oživljavaju. Haptičko se ovdje ne sastoji u nejasnim slikama, nego u poniranju u stvari, u kuću, u male stvari koje podražavaju 
intimnu taktilnost organizma kuće i ljudi, s neanimiranim predmetima, lutkama, noževima, češljevima, metlama itd. Opresivna prisutnost mnoštva sitnih predmeta prisiljava pogled da klizi preko teksture tih detalja, preko sive patine, trulih parketa i ormara, dakle postaje osjetilan, haptički pogled.

Poziciju Laure Marks ovdje možemo čitati kroz prizmu Deleuzea i Guattarija. Bilo da se radi o taktilnosti interkulturalnog filma ili taktilnosti eksperimentalnog filma, kroz sinesteziju subjekti pokušavaju naći utočište. A to se utočište više sastoji u bijegu, bježanju u domovinu koja poprima fluidno, nestabilno značenje, kao original koji je skoro nemoguće prevesti. U tom kontekstu original i prijevod, domovina i interkulturalni film, ili film isključenih, približava se Deleuzeovu i Guattarijevu poimanju haptičke slike kao pokušaja izlaza iz sustava kontrole; sugerira nepokorenost, zavaravanje sustava despotske moći koji nas želi pokoriti.[?]

Deleuze i Guattari presudni su za Marks i njenu teoriju haptičke slike u filmu. Kao potvrda njihove važnosti, oni se javljaju u njenom snu pred kraj knjige Touch, Sensuous Theory and Multisensory Media, točnije u jednom od deset snova kojima ona ilustrira isprepletenost svoje podsvijesti s mijenama u filmskim praksama i teorijama tijekom posljednje dekade. Jedan od snova je opis njena boravka u Deleuzeovoj kući: „Sanjala sam da moj uzor, Gilles Deleuze drži predavanje, te poslije svi koji su prisustvovali idu u njegovu kuću. ... Deleuzeova kuća je velika i prazna, izgleda kao skupi bunker od cementa koji nema ni jednog prozorčića, unutra nema ništa samo ilustracije, bazen i jacuzzi. Deleuze sjedi za barom i prodaje piće." (Marks, Touch 206).

Gospodar, uzor dakle sjedi u praznini, kao figura u praznom prostoru. No, bez obzira na veliku ulogu Deleuzeove i Gattarijeve teorije o haptičkom u radu Laure Marks, za nas je upravo njeno čitanje njihove teorije mjesto prijepora kroz koje otkrivamo i neke druge dimenzije haptičke filmske slike, kojima se Marks ne bavi. Marks, slaveći osjetilno kormilarenje kroz gustoću pojavnosti, često gubi iz vida optičku dimenziju filmske slike, koja je za Deleuzea i Guattarija neizostavno povezana s haptičkim. U sljedećem dijelu proširujemo njeno čitanje haptičkoga kako bismo ukazali na nove teorijske mogućnosti.

\section{Haptički film: horor haptičko, orijentalno haptičko i kozmičko haptičko}


Čovjek koji sjedi u sobi, ljudska figura i prostor sobe, statičan američki plan u filmskoj terminologiji. Tu, na najjednostavniji način, počinje Deleuzeova studija o Francisu Baconu u kojoj se bavi problemom figure (figuralizacijom) i pozadinom. Opstojnost čovjeka koji sjedi, meso poduprto kostima, kao da je u potpunosti izdvojen. Ukoliko je blizu druga figura, odmah dolazi do relacija, koje mogu postati naracije. Tajna haptičke slike, za Deleuzea, krije se u odnosu između figure i pozadine. Postavlja se pitanje koja je uloga i svrha pozadine te što se događa kada zapravo nema renesansne perspektive u slici. Za Deleuzea Baconov se rad opire narativnim relacijama između figura i fokusira se na „brutalnost činjenice”, golu prisutnost. Da bi objasnio taj pristup Deleuze podvlači razliku u praksi gledanja, između optičkog i haptičkog gledanja te se pritom poziva na rad povjesničara umjetnosti Aloisa Riegla, kojeg smo već spomenuli u uvodnom dijelu ovog rada.

Alois Riegl, prema Deleuzeu, dijeli povijest umjetnosti na tri estetska načela na kojima počivaju egipatska, grčka i romanska umjetnost. Zajedničko je svim pravcima težnja da se prezentiraju vanjski objekti kao materijalni entiteti, to jest da se na razne načine označi vanjski prostor, okoliš. Najjednostavniji način da se izdvoji pojedini objekt iz kaosa vizualne percepcije, da se izolira u svojoj objektivnosti, po Rieglu, upravo je kroz dodir koji, naravno, ne može obuhvatiti totalitet, cijelu površinu objekta, već samo pojedine dijelove. Kako bi se objekt mogao shvatiti, potrebno je puno dodira, umnažanje dodira, koje će postepeno dovesti svijest u određeni red. Kako bi se shvatio objekt, potrebno je ujediniti taktilnu i optičku sferu - ruku i oko - optičko će kasnije nadvladati, ali nikad do kraja potisnuti haptičku dimenziju. U egipatskoj slici nema pozadine, sve je u jednom planu, što navodi na haptički pristup s naglaskom na teksturu i materijalnosti. Nasuprot tome figurativni prikaz izdvaja figuru i pretvara okolinu u apstraktni prostor, nasuprot haptičkom gledanju koje dodiruje sliku, daje prednost iluziji prostora, apstraktnome beskonačnom prostoru. U haptičkoj dimenziji slike, Deleuze navodi da sâm prostor postaje taktilan, kao da je oko ruka koja gladi i prelazi površinom slike, nikada ne obuhvaćajući cijelu konfiguraciju slike. Jedino se u virtualnom prostoru ti razni elementi i percepcije mogu okupiti, no to okupljanje ne garantira nikakvu stabilnost, sve je u neprestanim varijacijama, nema stabilnog seta referenci, prisiljeni smo stalno tražiti novu orijentaciju.

U knjizi A Thousand Plateaus, Capitalism and Schizophrenia haptičko je za Deleuzea i Guattarija posebna vrsta „nomadske” umjetnosti. Haptičko počiva na blizini, na vizualnosti koja je blizu 
predmeta, za razliku od gledanja koje je izdvojeno i uključuje vizualnost na daljinu. Preferiraju izraz haptičko, a ne taktilno jer taj termin nadilazi opoziciju između vizualne i taktilne percepcije (taktilnosti kao fizičkog dodira). Za njih je haptički prostor "gladak” prostor, fluidan i intenzivan, kojim se može prolaziti jedino u bliskom odnosu s neposrednom okolinom, a ne pomoću apstrakcija kao što su mape i kompasi. Percepcija počiva na materijalnoj singularnosti objekata, kao kad osoba hoda kroz snijeg ili pijesak. Taj je prostor ujedno najpovoljniji za nomadsku umjetnosti, jer odiše imanentnom intimnošću. U glatkom se prostoru živi neposredno, bez jasnog razgraničenja između subjekta i objekta, tijelo je asamblaž poveznica, tijekova i afekata. „Naborani prostor" baziran je na hijerarhiji, promatranju i kontroli, on je imperijalan (Deleuze, Francis Bacon). Međutim glatki i naborani prostor, baš kao haptički i optički, ne mogu se apsolutno distancirati; štoviše često klize jedan u drugi. Drugim riječima, i jedan i drugi fuzioniraju se u original u energetskim strujanjima neprestanog prevođenja. lako se povodi za Deleuzeovom i Guattarijevom teorijom, Marks, zapravo, više opisuje taktilno s fenomenološkog stajališta, usredotočujući se na središte percepcije te još uvijek zadržava dihotomiju između subjekta i objekta. Za Deleuzea i Guattarija subjekti i objekti nisu odvojeni entiteti, ali, iako između njih ne postoje rigidne granice, oni nisu i ne mogu biti promatrani kao jedinstvo. Subjekti i objekti su u neprestanom pokretu, energije u pokretu, fragmenti koji se mogu beskonačno povezivati na različite načine, tvoreći asamblaž koji „nema ni bazu ni superstrukturu, nema ni dubinske kao ni površne strukture” (Deleuze, Francis Bacon 90). Asamblaž čine privremene veze između ljudskog, životinjskog, neljudskog, organskog, neorganskog i između njih ne postoji ontološka razlikovnost, tj. hijerarhija. U tom kontekstu treba postaviti pitanje haptičke slike. Deleuzeovo pitanje u knjizi o Baconu: može li suvremena umjetnost nadići figuraciju, a ne završiti u apstrakciji (19), to jest postoji li mogućnost figuracije u apstrakciji, u kontekstu filma mi čitamo kao pitanje o mogućnosti iskoraka između narativa (apstraktnoga), koji slaže realnost, i senzibilnoga, to jest taktilnoga. Slijedeći Deleuzea možemo reći da postoje dva fundamentalna načina: (1) pokretom preko figuracije, to jest naracije ili (2) uranjanjem u figuru. Već na početku svog teksta, opisujući usamljenu figuru koja sjedi na stolcu u polupraznoj sobi, Deleuze napominje kako priča uvijek teži relaciji, gibanju u prostoru između dvije figure kako bi animirala naznačenu cjelinu. Zato je brutalna izolacija, izdvojenost, ujedno i najjednostavniji način dostatan da ugrozi prezentaciju, zbuni narativne silnice, ili barem privremeno primiri pripovijedanje. Dok optičke filmske slike proizvode i postavljaju izdvojene 
elemente figuracije u apstraktni prostor koji proizvodi iluziju punine, haptičke slike narušavaju hijerarhiju u percepciji, privlače pozornost na detalje, na materijalnost u kojoj se figura i pozadina gotovo stapaju u jedan plan. Upravo je krupni plan, toliko slavljen u ranoj filmskoj teoriji i praksi, kao spoznaja, emocija koja nas približava svijetu, ujedno i prostor gdje se u svojoj ambivalentnosti pretaču optičko i haptičko jedno u drugo. Krupni plan u kontekstu Deleuzea signalizira gubljenje figure, ali to gubljenje nužno ne završava u apstrakciji. Zapravo gubljenje figure - u filmskom krupnom planu - predstavlja krajnju ambivalentnost. Ta nestabilnost može prouzročiti suprotni efekt od "dodirivanja aure” ili „prizivanja memorije u trans-objektima” o kojima govori Marks. Ona može skliznuti iz „poznatog” u „nepoznato”, ono što Freud naziva haimlich i unhaimlich (sablasno). Haptički osjećaj pojačava gubljenje razlike između subjekta i objekta, gospodarenje poljem vidljivoga, što izaziva osjećaj nelagode, ugroze ili gubljenja orijentacije u prostoru, užas u kontaktu s Drugim ili nadrealistično gubljenje u prostoru. Kinetička tjelesnost, mesnatost filmske iluzije ovdje izaziva šok, kao da samo tijelo odgovara na nelagodu, ili na osjećaj tjeskobe i pomutnje. U tom smislu u raspravu uvodimo mogućnost onoga što nazivamo horor haptičko, orijentalno haptičko i kozmičko haptičko. O horor haptičkom govorimo kad ta ugroza doživljava vrhunac; o orijentalnom haptičkom kad se subjekt susretne s radikalnim Drugim i nepoznatim pejzažem, a o kozmičkome haptičkom kad se total rastvara u košmarnom. Važno je napomenuti da se ova podjela ne odnosi na žanrovsku klasifikaciju i ne iscrpljuje tematiku haptičkog pogleda.

Na primjer, horor haptičko možemo naći i u nekim krupnim planovima u filmu Davida Lyncha Blue Velvet (1986) kad kamera napušta idilični krajolik maloga američkog gradića, otjelovljenje američkog sna pedesetih godina prošlog stoljeća, i uranja u travu, u sve veću travu te kad smo unutra kao u prašumi i čujemo prijeteće zvukove. Naravno, ovo ulaženje u minijaturni svijet uprizoruje i razliku između površine i dubine, u samoj haptičkoj prisutnosti krije se užas koji podriva optičko koje ga želi obuzdati, a samim tim ujedno podriva i narativno. Odsječeno uho koje se našlo u toj travi nalik prašumi pojačava osjećaj ugroze, kao objekt iz horor filma koji uznemiruje čitavu konstrukciju, u ovom slučaju referencu na stereotipnu sliku o idili, o savršenom skladu, o malograđanskom životu, vrtovima, automobilima, itd. To je ujedno i podrugivanje standardiziranim stereotipima koji oživljavaju sâm period: sladunjava pop glazba pedesetih, glasovi koji asociraju na tvrdo kuhanu prozu, dizajn odjeće itd. Krupni plan, koji poništava i figuru i pozadinu, dovodi nas u 
intiman odnos s prikazanim objektom te postaje uznemirujući, jer nam prikazuje nešto što nam je blisko (dio ljudskog tijela), nešto što je organsko, a doživljavamo ga kao anorgansko, kao neku čudnu materijalnost. ${ }^{[8]}$

Kad se nađemo u nepoznatom teritoriju, to jest kad nas filmske slike obasipaju krajobrazima, čak i totalima, a mi se u tome ne možemo snaći, dolazimo blizu onoga što zovemo orijentalno haptičko. Orijentalno haptičko tiče se se, zapravo, kobnog susreta s Drugim. Na primjer, u filmu Philippea Grandrieuxa La Vie Nouvelle (A New Life) (2002) filmska sekvenca pred kraj filma proizlazi iz tehnološkog aparata - termo kamera za noćno snimanje putem svjetlosnih senzora pretvara ljudske figure u različite sivkaste mrlje, ljudska tijela se transformiraju u monstruozna stvorenja bez očiju, svjetlucave, titrave siluete koje podsjećaju više na životinje nego na ljude, koje zavijajuju i jure uokolo, napadajući jedni druge. Neke figure još nisu prešle iz figurativnosti u apstrakciju, još uvijek su u zamućenim ljudskim obrisima, ali ti bljedunjavi tragovi koji još uvijek asociraju na ljudsko tijelo neprestano se gube pod pritiskom čudovišne metamorfoze. Haptičko je ovdje u dvostrukom smislu: toplina koja izvire iz tijela je ta koja ujedno i stvara osebujnu filmsku sliku u termodinamičkom snimanju, nalik onim starim otiscima negativa prilikom razvijanja filma u laboratoriju, istodobno ono što postaje vidljivim putem topline i dodira postepeno ili naprasito gubi svoje obrise, upozoravajući nas na snagu filma da stvori, ali i rastvori ljudsku figuru u sivkasti mlaz, bljedunjavi obraz koji asocira na bezlično strujanje materije (Brenez) ${ }^{[9]}$ Kao da to rasplinjavanje zamućuje i samu priču. Tek u mutnim obrisima možemo shvatiti narativ: radi se o ljudima koji bježe preko granice, a tek upućeniji ili pažljiviji gledatelji mogu povezati taj kaotični prizor s ratom na Balkanu devedesetih godina prošlog stoljeća, zajedno s trgovinom ljudima, prostitucijom, besmislenim nasiljem ${ }^{[10]}$

Upravo u odnosu ljudske figure i pozadine, to jest od haptičkog gubljenja u vizualnim slikama, gdje se oko kao ruka, kao taktilni organ nastoji orijentirati, do optičkoga, dakle širega, koje označava da se nalazimo u zemlji radikalne Drugosti, tamo gdje je sve dopušteno, na Balkanu, krije se orijentalno haptičko. Važno je naglasiti da baš kao što Deleuze analizira moment mogućnosti prelaska iz figure u figuralizaciju koja neće završiti u praznom beskonačnom prostoru, to jest apstrakciji, mi postavljamo pitanje je li moguće - u najradikalnijim situacijama - predočiti Drugoga, a da se na završi u apstraktnosti stereotipa? Orijentalno haptičko puno je paradoksa, to jest odnos 
optičkoga i haptičkoga prelazi u krajobraz, odnos dakle zahvaća daleko šire vidljivo polje koje je uglavnom uvijek pripisivano optičkome. Ovdje bi haptičko bilo gotovo nemoguće sagledati bez optičkoga: sama prisutnost titravih, izobličenih ljudskih figura registriranih okom termo kamere bez narativa bila bi samo filmski eksperiment, eksperiment naizgled lišen konteksta, to jest svoje političke dimenzije.

Od krupnog plana, horora, sjecišta ambivalentnosti optičkoga i haptičkoga, do orijentalnoga, kada se nasilno dezintegrira ljudsko tijelo i gubi ona sigurna distanca koju njegujemo pogledom, dolazimo do krajnjeg paradoksa, to jest postavlja se pitanje može li nas filmski total, ili sekvenca iz ptičje perspektive toliko zavarati da na momente postaje haptička? To kozmičko haptičko možemo vidjeti u filmu Gaspara Noe, Enter the Void (2009). Naracija filma često se gubi, kao i figurativno i optičko kako ga postavljaju Deleuze i Guattari jer većinu filma gledamo Tokio, cijeli suvremeni megapolis, iz perspektive Oskara, dvadesetogodišnjeg Kanađanina. Oskar na početku filma uzima DMT, jednu od najjačih psihodeličnih droga, te se upućuje s prijateljem Aleksom prema Love Hotelu (Hotelu ljubavi), ogromnom kompleksu bordela. Na putu zastaju u baru Kabukicho, u dijelu grada poznatom po prostituciji. Bar se zove Void (praznina). Okruženi tv monitorima na kojima se prikazuje Kubricov 2001: A Space Odyssey (1968) pregovaraju o prodaji droge. Međutim, nešto pođe po zlu i Oskar je ubijen. Leži kao fetus ispod pisoara u uskom, klaustrofobičnom toaletu, njegov duh napušta tijelo i uzdiže se u visine. I u svom zagrobnom životu osjeća psihodelične fantazije, vidi svjetlucave oblike koji nalikuju budističkoj mandali, dok lebdi iznad visokih nebodera digitaliziranog, neonskog metropolisa. U pojedinim sekvencama vidimo total Tokija iz ptičje perspektive: velika kristalna, svjetlucava mreža koja se neprestano grana, čiji se obrisi gube u kjaroskuro svjetlu neona. Zgrade i stvari blijede u neonskom svjetlu metropole, čiji se kraj ne nazire. Čini se da se cijeli grad proteže u beskonačnost - Tokio kao kozmopolis. lako snimljeno u totalu, urbano tkivo postaje nerazumljivo, nepovezano, miješa se s Oskarovim memorijama, noćnim morama, katkada cijela urbana panorama postaje mjesto Oskarovih previranja. Možemo reći da gubljenje orijentacije u totalu proizlazi iz pokušaja da se total obuhvati haptičkom slikom. Opipavanje ili Oskarova taktilna navigacija približna je onome što Deleuze i Guattari zovu „glatki prostor". Glatki prostor prolazimo haptičkim načinom, kao kad se borimo sa snijegom ili pijeskom, neprestano se baveći bliskim objektima, on je izvorište „nomadske umjetnosti”. Nasuprot tome 
postoji „naborani prostor” koji korespondira optičkom senzoriju i ustanovljuje imperijalni pogled, koji kontrolira cijeli teritorij. Ta dva prostora u filmu implodiraju u Hotelu ljubavi kada se Oskarov duh strmoglavi u jedu od soba hotela i približi golom tijelu svoje sestre. Sestra se grči u seksualnom zanosu dok on žudi skriti se u njezinoj utrobi, incestualno se ugnijezditi u njezinoj maternici. I ulazi u tijelo, u težnji da se nastani u oplođenim jajašcima, da se u obnovi u toj psihodeličnoj reinkarnaciji, opet rodi. Njegovo tijelo, posljednji dah, osjet polako nestaju u haptičkoj slici, koja u kamuflaži reinkarnacije prikriva nestanak figure, kao organizam koji prikriva Deleuzeov i Guattarijev koncept - „tijelo bez organa”. Za njih se tijelo ne može promatrati kao unificirani organizam, biološki ili tjelesni, organiziran u smislu nesvjesnoga i svjesnoga. Oni vide tijelo kao fragmente želje, stroja žudnje. Tijelo bez organa je tijelo nastanjeno mnoštvom, intenzitetima (Deleuze and Guattari 30). Tijelo bez organa je fluidno, kao jaje koje umjesto tri supstance ima nesmetan protok (Deleuze and Guattari 153). Figura se gubi u nasilnom miješanju razlika. Tijelo postaje intenzivna vibracija koja se opire bilo kojoj reprezentaciji. „Mi znamo da jaje otkriva stanje tijela prije reprezentacije: vektori i horizontale, stupnjevi, zone, kinematički (filmski) pokret, dinamične tendencije u relaciji sa slučajnim formama" (Deleuze, Francis Bacon 45).

Dakle, u unutrašnjosti otkrivamo haptičku sliku koja ujedno u kinematičkom pokretu guta šire vizure (total), jer „tijelo bez organa” (jaje) urušava navedene distinkcije, utjelovljuje vektore i horizontale silnica, ono je čisti intenzitet.

Ni navedeni primjeri ni predložene klasifikacije, dakako, ne iscrpljuju područje haptičkoga, koje je, kao što smo pokazali, neprestano u suodnosu s optičkim, širim predjelima. Haptička slika odaje impresiju kao da smo nešto vidjeli prvi put: detalj nečijeg lica u krupnom planu, košmarni krajolik koji istražujemo kao putnici, pa sve do snolikog predjela koji se čini beskonačnim. To što smo vidjeli prvi put usporava percepciju, uneobičuje obično, začuđuje banalno. Budući da nismo tabula rasa, budući da smo uvijek nečim ispunjeni, to stanje ubrzo klizi u povezanost, u narativni lanac te dobiva ili mijenja značenje. U horor haptičkome moguće su sve varijacije doživljaja, viđenja itd. Naracija filma katkada nas vodi u klopku gdje smo prisiljeni na sučeljavanje s haptičkom stravom i užasom pa želimo izaći, ali najčešće su ti odnosi isprepleteni. U haptičkom orijentalizmu radi se o inverziji: odjednom smo se našli u košmarnoj situaciji koja vrvi haptičkim slikama, a onda, budući da ne možemo izdržati takvo stanje, bježimo u naraciju, tj. podvrgavanje Drugoga. U krajnjem vidu, 
kozmičkom haptičkom, kao što je to slučaj s Tokiom u filmu Enter the Void, nedoumice i ambivalentnosti krupnog plana prenose se na total.

\section{Prevođenje}

Ako promatramo haptičku sliku kao prevođenje u širem smislu, iz jednoga osjetila u drugo, iz vizualnoga u taktilno, onda se postavlja pitanje o vezi između originala i prijevoda. Haptička vizualnost je način gledanja u kojem se služimo očima kao rukama, gdje su oči organ dodira, kao da dodirujemo objekte našim očima. Često se doživljava kao način gledanja koji ne postavlja nasilnu distancu između gledateljstva i objekta te ne prozračuje bol koja proizlazi iz toga nasilnog razdvajanja. Kontakt s predmetnom pojavnošću kao nježni dodir, kao blago glađenje prisutnosti objekta, često se tumači kao nešto što podriva metafiziku prezentacije. Marks u svom pisanju o filmu inzistira upravo na tom „nježnom osobnom”, u namjeri da ustoliči haptičku kritiku koja bi bila osobnija, koja bi istraživala taktilnu prisutnost Drugoga, u vjeri da ga neće podjarmiti, strpati u stereotipe. Drugim riječima, haptička kritika je pokušaj prevođenja koji se neće moći pokoriti apstraktnim načelima. U tom smislu Marks vjeruje da je haptičko nešto što garantira slobodu ekspresije, to jest za nju haptičko predstavlja otpor optičkoj vizualnosti, koja je u suštini imperijalna, na kojoj počivaju različiti oblici vladanja i gospodarenja. Štoviše, inspirirana Deleuzeom i Guattarijem, ona ističe da je prevaga optičke vizualnosti zapravo utjelovljenja u zapadnoeuropskoj metafizici koja služi podjarmljivanju Drugih i različitih.

Deleuze i Guattari zaista gaje nadu da se haptičko opire kontroli, i upravo je taj dio najviše inspirirao Marks u njenom postavljanju haptičke filmske teorije. Naš cilj nije slijediti Deleuzea i Guattarija u potpunosti, već upravo suprotno, koristiti njihovu misao kako bi iznova promišljali i razvili kritički odnos prema filmskoj prezentaciji, ili bilo kojoj prezentaciji, te na taj način otvorili mogućnost za promišljanje novih realnosti, novog odnosa spram Drugosti. Ukoliko je u pitanju „prevođenje”, onda odnos haptičkoga i optičkoga ne može biti fiksiran u dihotomiji, konstrukciji u kojoj je haptičko zalog slobode, kao neko područje slobode kao takve. Pretpostavljati haptičko a priori kao mogućnost slobode ponovo uspostavlja bipolarnu poziciju, a ona, prema našem mišljenju, ponavlja stare strukturalističke opreke koje, zaogrnute novim nazivljem i novom retorikom, žele fiksirati i ovladati Drugim, samo na drugačije načine. U našem pak promišljanju 
filma to bi značilo da haptičko (u slučaju Marks haptička dimenzija interkulturalnog i manjinskog filma) osporavajući optičko, biva fiksirano kao takvo, pa iako na margini, postaje kanonizirano.

Ovdje je važno napomenuti da iako Deleuze i Guattari u A Thousand Plateaus govore o haptičkom kao o nečemu što može izmaći kontroli. U svojim tekstovima koji se odnose na „društvo kontrole” oni pišu kako politike kontrole na mirkorazinama mogu usisati u sebe svaku opoziciju, a prema našem mišljenju tako i haptičko i elemente slobode koji mu se a priori bez problematiziranja pripisuju (Deleuze, Postscript 3-7).

Štoviše, kao što smo pokazali u ovom radu, taj isti moment „slobode” može naglo eruptirati u stravu i užas (često korišten upravo u komercijalnim horor filmovima). Isto tako, u različitim vidovima, haptičko može dovesti do orijentalnog haptičkoga, zapravo krajnjeg užasa susreta s radikalnim Drugim (izvan zapadnoeuropskoga kulturnog i ekonomskog konteksta), a na kraju i do kozmičkog haptičkog - motiv koji se često javlja u cyberpunk fikciji, na primjer u Neuromanceru, u Gibsonovu romanu pisanom 1980. godine, gdje vlada „SimStim” (simulirani stimulans), sustav koji simulira ne samo vizualne organe, kao naslon računala ili televizijski prijemnik, nego i ostala osjetila - dodir, okus, miris. Zapravo ta virtualna realnost ukazuje na tehnološke i medijske mogućnosti da ovladaju haptičkom filmskom slikom, u svrhu zabave, kontrole, i, dakako, oplođivanju profita u novim vidovima kapitalizma; izdvojena kao autonomni centar reprezentacije koji odjednom biva prijeteći narušen.

Po našem mišljenju problem figure o kojem Deleuze govori u tekstu Francis Bacon: The Logic of Sensation ukazuje na krajnju nestabilnost prezentacije, na upitnost bilo koje datosti, bilo optičke ili haptičke:

Kršćanstvo je pokorilo formu, ili Figuru u radikalnoj deformaciji. Ukoliko je Bog utjelovljen, raspet na križu, spustio se na zemlju i uzdigao u nebesa, forma Figure više nije nužno vezana za esenciju, nego krajnjoj suprotnosti: događaj, nečemu promjenjivom, slučaj. Kršćanstvo u samoj svojoj srži sadrži sjeme ateizma koje će rasti u slikarstvu, slikar može biti indiferentan prema religioznoj temi koju treba prikazati. Slikaru ništa ne stoji na putu da to prihvati, jer je odsada ono vezano uz slučaj... Moderno slikarstvo počinje kad se čovjek ne doživljava više kao esencija nego kao slučaj. (124) 
„Slučaj” donosi novu konfuziju kontekstu prevođenja iz jednog medija u drugi: što bi bio „slučaj” u taktilnom, predmetnom, u neposrednoj blizini. Bi li taj „slučaj” označavao nešto što lebdi iznad predmetnosti (transcendentalnu dimenziju) ili je on imanentan predmetu. Ako se pak prelazak optičkoga u haptičko može promatrati kao prevođenje, onda ne samo da „slučaj” usložnjava čitav proces, već dovodi do ključnog argumenta našeg eseja. Ukoliko je jedna od najvažnijih dimenzija interkulturalnog filma prevođenje strukturalne nejednakosti i nepripadnosti u haptičku dimenziju, kakva je onda ta „domovina” u koju se želi prevesti. Paralelno s tom tezom, mi razmatramo haptičko kao prevođenje iz jedne percepcije u drugu, iz jednog osjetila u drugo. Za razliku od Marks koja tvrdi da su neverbalne senzacije bliže tijelu, i da kao osjet dodira mogu arhivirati daleko snažnije emocije i memorije koje su izgubljene u vizualnom, mi tvrdimo, da su i one prevodive. Pitanje je samo kako? A to pitanje, kao što je naglasio Benjamin, uvijek dovodi od lingvističkoga do širega filozofskog odnosa između originala i prijevoda (pa u postmodernom kontekstu i pitanja kopije kao novog originala). Prisjetimo li se Benjaminova teksta o prevođenju, gdje on tvrdi da prevođenje iz jednog jezika u drugi implicira potenciju određenog jezika da bude prevodiv te da je ta prevodivost osnovno načelo svih prevođenja, koje u sebi sadrži odnos između prevedenoga i originala, dolazimo do ključnog pitanja o samoj prevodivosti, kao i pitanja o prevodivosti Drugosti (Benjamin 254). Kao što Viveiros de Castro tvrdi, inspiriran Benjaminom i Deleuzeom, bilo koja Drugost, da bi bila prevodiva, mora istovremeno biti predstavljena kao „Drugo”, ali i kao djelomična „Istost”, jer možemo komunicirati s njom (Hage). Za Benjamina prevođenje je uvijek komunikacija koja je svojevrsna izdaja destinacije, a ne originala. Stoga se, po Viveiros de Castru, trebamo otvoriti originalu, „dekolonizirati naše misli” te omogućiti prevođenje koje će dozvoliti subverziju, kako bi se original mogao iskazati kao nešto novo (5). Po samom načelu prevodivosti, original je uvijek blisko povezan s prijevodom, a Benjamin pojašnjava tu vezu uspoređujući je sa životom i fenomenom života, drugim riječima, prevođenje svjetskih klasika, uvijek naknadno, produžuje i transformira život originala. Ovdje se život ne uzima kao metafora (Benjamin 261). Život je ono što se prevodi, život koji proizlazi iz „slučaja”, život kao original, kao sjedište svih percepcija, osjeta, haptičkih i optičkih slika. Taj paradoksalni odnos originala i prijevoda, u kome se prevođenje samog života, dakle „slučaja” u odnos riječi (filmske slike) i originala, to jest treće stvari koje one označavaju, može nazvati čisti jezik (ili čisti film). Čisti film, ili kako ga mi zovemo heretički film, 
referira prevođenje osjetila i medija na sinestezijsku simfoniju, pozivajući se na Benjaminovu opasku da se zapravo u krajnjem slučaju radi o životu, to jest da je krajnji čin prevođenja prevođenje života u imanentnu domovinu, što bi značilo bez nasilja. Viveiros de Castrova „dekolonizacija misli” ujedno je i krajnja politička dimenzija filma.

\section{Bibliografija}

Ahmed, Sara. The Cultural Politics of Emotion. Routledge, 2004.

Barker, Jennifer. The Tactile Eye: Touch and the Cinematic Experience. University of California Press, 2009.

Benjamin, Walter. "The Task of the Translator". Walter Benjamin: Selected Writings, Volume 1, 1913-1926, edited by Bullock, Marcus, and Michael W. Jennings, Harvard University Press, 2002, pp. 253-63.

Beugnet, Martine. Cinema and Sensation: French Film and the Art of Transgression. Edinburgh University Press, 2007.

Brenez, Nicole. The Body's Night: An Interview with Philippe Grandrieux. Translated by Adrian Martin, Rouge, 23 Oct. 2002, www.rouge.com.au/1/grandrieux.html. Accessed 18 Jan. 2018.

Bruno, Giuliana. Atlas of Emotion: Journeys in Art, Architecture, and Film. Verso, 2002.

Deleuze, Gilles. Postscript on the Societies of Control. October, vol. 59, 1992, pp. 3-7.

Deleuze, Gilles. Francis Bacon: The Logic of Sensation. Continuum, 2002.

Deleuze, Gilles, and Felix Guattari. A Thousand Plateaus, Capitalism and Schizophrenia. Continuum, 2004.

Freud, Sigmund. Uncanny. Penguin Classics, 2003.

Gregg, Melissa, and Gregory Seigworth, eds. The Affect Theory Reader. Duke University Press, 2010.

Hage, Ghassan. "Critical Anthropological Thought and Radical Political Imaginary Today." Critique of Anthropology, vol. 32, no. 3, 2012, pp. 285-308. 
Jameson, Fredric. Representing Capital: A Reading on Volume One. Verso, 2011.

Keller, Sarah, and Paul Jason, eds. Jean Epstein, Critical Essays and New Translations.

Amsterdam University Press, 2012.

Marks, Laura. The Skin of the Film, Intercultural Cinema, Embodiment, and the Senses. Duke University Press, 2000.

Marks, Laura. Touch, Sensuous Theory and Multisensory Media. University of Minnesota Press, 2001.

Massumi, Brian. Notes on the Translation and Acknowledgments. A Thousand Plateaus, Capitalism and Schizophrenia, by Deleuze, Gilles, and Felix Guattari, Continuum, 2004, pp. xvi-xix. Shaviro, Steven. Post Cinematic Affect. John Hunt Publishing, 2010.

Stam, Robert. Film Theory: An Introduction. Blackwell Publishing, 2000.

Stewart, Kathleen. Ordinary Affects. Duke University Press, 2007.

Viveiros de Castro, Eduardo. "Perspectival Anthropology and the Method of Controlled

Equivocation." Tipiti: Journal of the Society for the Lowland South America, vol. 2, no. 1, 2004, pp. 3-22. 
[1] Vidi: Keller and Jason.

[2] Tako za antropologinju Kathleen Stewart afekti se odnose na impulse, osjetilnosti, dnevne snove, dodire, susrete, različite načine pripadanja, angažiranja, sve što čini ljudsko iskustvo. Oblikuju se u smislu teksture u trenutku svog prolaska kroz tijela, snove, društvene svijetove svih vrsta.

[3] Vidi: Bruno.

[4] Vidi na primjer: Barker. Inspiriran Deleuzovom i Guattarijevom konecptualizacijom haptičkoga je i Steven Shaviro. Vidi: Shaviro, ili Beugnet.

[5] Ovdje želimo napomenuti da i afektivni obrat u društveno-humanističkim znanostima otvara cijeli niz novih pitanja u svezi haptičkog filma i emocija kao kulturnih praksi, a koje ne obrađujemo u ovom tekstu. Na primjer Sara Ahmed u svom radu govori o ekonomiji emocija te ukazuje na krucijalnost emocija za konstituciju različitih društvenih granica, pa i samih objekata emocija. Ono što cirkulira za Ahmed nisu same emocije, već objekti emocija (1-20). Nadalje, kao što Stewart naglašava, možemo pristupiti osjetilima, u ovom slučaju taktilnosti filma, kroz afekte koji in omogućuju te ukazati na njihov značaj kroz analizu intenziteta koji grade, analizu potencijalnih modela znanja koji su već u njima, i potencijala koji su kroz njih otvoreni.

[6] Vidi: Jameson. U hegelijanskoj varijaciji na temu kako predmet postaje roba, Jameson često analizira kako se u suvremenoj globalizaciji potiskuju uvjeti rada u zemljama Trećeg svijeta. Iako se on ne poziva na haptički element, mi mislimo da u globalnom imaginariju svjetskog tržišta upravo haptički element odgovara kulturnim memorijama radnika koju su sudjelovali u proizvodnji pojedine robe.

[7] Ovdje je važno naglasiti da teoretičar i prevoditelj Deleuzea i Guattarija na engleski jezik, Brian Massumi, navodi da na francuskom Fuite znači ne samo čin bježanja ili izmicanja nego i tijeka, curenja, nestajanja u daljini, a isto tako odnosi se i na letenje (xvi).

[8] Beugnet, Martine u svojoj knjizi Cinema and Sensation: French Film and the Art of Transgression naglašava kako tijelo - posebice ljudsko tijelo - otkriva kroz krupne planove zastrašujuće dimenzije. Ogromne bore, prištevi, tekstura kože koja može izgledati kao ispucana 
suha zemlja itd., sve to postaje nepoznat krajolik neke nove čudne materijalnosti. Ovdje koristimo Beugnetinu tezu kako je filmski krupni plan borba između optičkoga i haptičkoga. Dok ona nadopunjuje i širi haptičko na film senzualnosti, mi se više fokusiramo na haptičko i specifično prevođenje.

[9] Grandrieux u intervjuu s Nicole Brenez.

[10] U filmu La Vie Nouvelle Balkan je prikazan kao metafizički prostor boli, ovdje je orijentalizam uzdignut na najveću moguću razinu, gdje su ljudska tijela, zajedno sa životinjama iskrivljena, titrava u patnji. Haptička filmska slika prevladava.

\section{(c) (i) ()}

Creative Commons Attribution-NonCommercial-NoDerivatives 4.0 International License 